\title{
WHO BUILT MASLOW'S PYRAMID? A HISTORY OF THE CREATION OF MANAGEMENT STUDIES' MOST FAMOUS SYMBOL AND ITS IMPLICATIONS FOR MANAGEMENT EDUCATION
}

\author{
TODD BRIDGMAN \\ STEPHEN CUMMINGS \\ Victoria University of Wellington, New Zealand \\ JOHN BALLARD \\ Mount St. Joseph University, Cincinnati, Ohio
}

\begin{abstract}
Abraham Maslow's theory of motivation, the idea that human needs exist in a hierarchy that people strive to satisfy progressively, is regarded as a fundamental approach to understanding and motivating people at work. It is one of the first and most remembered models encountered by students of management. Despite gaining little support in empirical studies and being criticized for promoting an elitist, individualistic view of management, Maslow's theory remains popular, underpinned by its widely recognized pyramid form. However, Maslow never created a pyramid to represent the hierarchy of needs. We investigated how it came to be and draw on this analysis to call for a rethink of how Maslow is represented in management studies. We also challenge management educators to reflect critically on what are taken to be the historical foundations of management studies and the forms in which those foundations are taught to students.
\end{abstract}

\begin{abstract}
"Why has the hierarchy of needs been so popular? The appeal of the pyramid image should not be underestimated ... Maslow might have chosen a different icon (e.g., a Native American medicine wheel) but it would not have had the same iconic appeal"
\end{abstract}

(Peterson \& Park, 2010: 320).

Abraham Maslow may be the most "iconic figure in the history of management ideas" (Cooke, Mills, \& Kelley, 2005: 133). Why? Largely because the pyramid or triangle ${ }^{1}$ of human needs is likely the most famous image in management studies. The idea that human needs exist in a hierarchy form, with basic, extrinsic needs at the bottom, and that employees are motivated to satisfy each need level as they progress up the pyramid until they realize their true potential

We are grateful to Lizette Royer Barton, MLIS, Reference Archivist at the Drs. Nicholas and Dorothy Cummings Center for the History of Psychology, the University of Akron, for assisting us in accessing the archives.

${ }^{1}$ Some sources we investigated present it as a pyramid; others present a triangle. For consistency and to avoid confusion, we refer to it as "pyramid" throughout; however, in most presentations of Maslow's theory it appears in two dimensions as a triangle. through the gratification of their "self-actualization," is typically the first theory of motivation presented to management students and the theory of management that they recall most vividly.

The pyramid is a useful point for management textbooks to start their presentation of motivation theories (often the first content described beyond introductory material), because it is seen to be "intuitively logical and easy to understand," and reinforces a commonsense view of human nature (Robbins \& Judge, 2015: 218; Schaller, Neuberg, Griskevicius, \& Kenrick, 2010). Students learn that managers should design work and benefits in a way that allows employees to satisfy their needs (Ballard, 2015: 32-33), thus leading to increased job satisfaction, commitment, and organizational performance. Some instructors and textbooks may suggest that skilled managers should understand where each of their employees is located on the pyramid and tailor their roles accordingly.

Management textbooks further ingrain the idea of Maslow's Pyramid in the minds of readers as they criticize Maslow and his theory. They claim it is simplistic to believe that people are motivated to satisfy just one category of need at a time; that a universal classification across all individuals and all 
cultures is problematic; and that, in any case, it is unscientific, being based on personal beliefs rather than objective evidence (Hitt, Black, Porter, \& Hanson, 2007; Robbins, Bergman, Stagg, \& Coulter, 2015). These criticisms are useful for textbooks' sequencing, as they describe the evolution of motivation theories from the early more basic approaches to the more advanced and sophisticated. For example, textbooks usually follow Maslow with a discussion of Clayton Alderfer (1969) and his ERG theory.

Although there is some variation in the naming of the five category levels in the image, what remains constant is the symbol that has become synonymous with Maslow: the pyramid. Two management books published on the initiative of Maslow's daughter, Ann Kaplan, make note of the "now famous pyramid" (Stephens, 2000: 1; Stephens \& Heil, 1998: xx). In Maslow on Management, (Stephens \& Heil, 1998, a reprint of Maslow's 1965 work Eupsychian Management, with an introduction by the editors), a pyramid motif appears at the start of each chapter, a testament to its significance. The online preface to a popular podcast, Talking About Organizations, sums up the common view: "What Maslow is most famous for ... is the pyramid of human needs" (www.talkingaboutorganizations.com/maslow/).

"Maslow's Pyramid" is pervasive beyond management studies. In psychology Maslow is regarded as one of its most eminent theorists of the last century (Haggbloom et al., 2002) so it is not surprising that the representation of his work has attracted attention (Koltko-Rivera, 2006; Wininger, \& Norman, 2010). In Perspectives on Psychological Science, Kenrick, Griskevicius, Neuberg, and Schaller (2010) asserted that "the powerful image of a pyramid of needs ... has been one of the most cognitively contagious ideas in the behavioral sciences" (p. 292). Drawing on developments in evolutionary biology, anthropology, and psychology, Kenrick et al. concluded that "the basic foundational structure of the pyramid is worth preserving, but ... it should be buttressed with a few architectural extensions" (p. 292). The significance of Kenrick et al.'s article is attested to by the four commentaries included alongside it. In their reply to these, Kenrick and colleagues (Schaller et al., 2010: 335) concluded that "people love a pyramid," and asked readers to ponder "exactly how might a Maslovian pyramid be most sensibly reconstructed in light of what we [now] know about human evolution?"

Many of the works that promote the pyramid, critique or seek to develop it, cite either or both of Maslow's two "classics" on his motivation theory: the 1943 article in Psychological Review and an edition of his book Motivation and Personality (1954, 1970, or 1987) to link the pyramid to Maslow. However, the pyramid does not appear in them (De Bruyckere, Kirschner, \& Hulshof, 2015; Eaton, 2013). We delved deeper to see if we might find how Maslow's Pyramid came to be.

Maslow was a prolific writer of personal journals (Maslow 1979a,b) as well as published work, with his bibliography containing more than 140 entries (Maslow, 1972). But having conducted an extensive search, including in the Maslow archives at the Center for the History of Psychology at the University of Akron in Ohio, we found no trace of Maslow framing his ideas in pyramid form. Further, we contacted a range of people whom we thought could provide personal insights: from Ed Schein, who worked with many of the people in this story, to others familiar with Maslow's involvement with Native American nations. Although they assumed that Maslow had developed the pyramid, they admitted that they could not recall his presenting it this way. We can say, with confidence, that Maslow's Pyramid (in the sense of him having created it) is a misconception, albeit a widespread and compelling one.

"But having conducted an extensive search, including in the Maslow archives at the Center for the History of Psychology at the University of Akron in Ohio, we found no trace of Maslow framing his ideas in pyramid form."

Our article builds on others that have noted the unhelpful, continual reproduction of Maslow's Pyramid in management textbooks (Fineman \& Gabriel, 1994) - either because it does not pass critical scrutiny (Watson, 1996), or because it was "merely a stepping-stone in the grand scheme of his work" (Dye, Mills, \& Weatherbee, 2005: 1380). That his intellectual contribution has been "bastardized ... and reduced to a parody" (Mills, Simmons, \& Helms Mills, 2005: 133) is a fair assessment.

Our contribution to this literature is to examine in detail how the pyramid came to be, as well as its negative effects. We uncover the role played by various individuals and institutions. In the 1950s, Douglas McGregor brought Maslow's psychological work into management studies, and Keith Davis adapted Maslow's idea to give weight to a fledgling field. In the 1960s, Charles McDermid promoted Maslow's theory in pyramid form, as a tool for consultants. Also, in this decade, the desire for management research to be more scientific saw Maslow's 
theory become a focal point for the emergent field of organizational behavior. In the 1970s and 1980s, textbook writers found the pyramid to be just the kind of illustrative content for which they were looking. From the 1990s through today, Maslow's Pyramid has taken on a life of its own in our culture, as an exemplar of effective visual communication and an easily adapted meme. This symbolism has seen the pyramid become more ingrained in our consciousness.

An understanding of the pyramid's origins can encourage us to think differently about how Maslow could be represented within management studies, to provide a more meaningful legacy than a symbol he never created. It can also be the catalyst for a deeper questioning of our field's historical foundations and how they are taught to students. Recent interest in reexamining these foundations shows that Maslow is not the only theorist whose ideas have been misappropriated. Were they alive today, founding "fathers," such as Adam Smith (Huhn \& Dierksmeier, 2016); Max Weber (Cummings \& Bridgman, 2011; Mills, Weatherbee, \& Durepos, 2014); Douglas McGregor (Jacques, 2006); and Kurt Lewin (Cummings, Bridgman, \& Brown, 2016) would have difficulty recognizing the ways in which their ideas are presented in textbooks. Meanwhile, in addition to these misrepresentations, the pioneering contributions of women and people from ethnic minorities are largely ignored (Cummings \& Bridgman, 2016; Prieto, Phipps, Osiri, \& LeCounte, 2017).

We return to that debate later in the paper. First, we begin with the case of Maslow's Pyramid and address the question of why it prevails and is so prominent in our teaching. The pyramid's popularity is not related to a clear filial connection to Maslow. Nor is it related to empirical validation studies, which have proven disappointing (Alderfer, 1969; Hall \& Nougaim, 1968; Porter, 1961). Furthermore, its ubiquity cannot be attributed to Maslow being the first psychologist to develop a theory of human needs. Langer (1937) presented a theory with physical, social, and egoistic needs. In an early human relations textbook, Strauss and Sayles (1960) included both Langer and Maslow. So how did Maslow's Pyramid come to pass, and how has its popularity grown?

\section{THE RISE OF THE PYRAMID: FROM OBSCURE HYPOTHESIS TO MANAGEMENT MONUMENT}

Although Maslow never presented his hierarchy of needs (hereafter HON) in a diagram or geometrically, there was once a competing shape used to present it. It was not a triangle or a pyramid, but a ladder (see, e.g., Wren, 1972). A Google n-gram search of the terms Maslow's Pyramid and Maslow's ladder reveals that the ladder was a common way of conveying the theory until the 1980s, when the pyramid became dominant. What follows is the story of how the pyramid rose to overcome this alternative representation, become synonymous with the HON, and establish itself as management's best-known theory.

"Were they alive today, founding 'fathers,' such as Adam Smith (Huhn \& Dierksmeier, 2016); Max Weber (Cummings \& Bridgman, 2011; Mills, Weatherbee, $\&$ Durepos, 2014); Douglas McGregor (Jacques, 2006); and Kurt Lewin (Cummings, Bridgman, \& Brown, 2016) would have difficulty recognizing the ways in which their ideas are presented in textbooks."

1950s:

Maslow to McGregor:

Monkeys, Sex, Motivation, Management

Maslow's early career developed within behavioral psychology. As a doctoral student at the University of Wisconsin advised by Harry Harlow, he studied primate behavior. In 1935 at a meeting of the American Psychological Association, he presented a paper on the relationship between dominance behavior and sexual behavior in monkeys. The chair of the session was the eminent psychologist Edward Thorndike. Thorndike offered Maslow a fellowship and research assistant position at Columbia University. In 1937 Maslow left Columbia and accepted a teaching position at Brooklyn College. Maslow was now on his own, free to pursue his own direction (Lowry, 1973).

In December 1941 Maslow had a revelation. Sitting in his car, watching a parade of veterans pass by, he reflected on the world going to war once again. At that moment, he resolved to devote his life to developing a "psychology for the peace table" (Hoffman, 1988: 148). Maslow wanted "a psychology that would speak to human potential and wholeness" (Ballard, 2006: 2). He saw biological needs as prepotent and needing to be satisfied, but once satisfied, higher level needs could emerge. Because of the prepotency of lower level needs, there must, he concluded, be a need hierarchy. In 1943 he presented his theory to a New York gathering of psychoanalytic psychologists and later that year published it in Psychological Review. 
The HON appears to have been well-received, but Maslow may have had no significant impact on management studies were it not for Douglas McGregor. McGregor encountered it in 1944 and drew on it in developing his famous Theory $\mathrm{X}$ and Theory Y concept. ${ }^{2}$ In 1956 McGregor wrote to Maslow after presenting the HON to a group of senior executives: "We had a long discussion on the implications of your self-actualization concept and it was quite clear that the whole idea not only made sense but fired their imagination because of its implications in industry" (McGregor letter to Maslow, November 16, 1956. Maslow Papers M395).

The reception by the executives fired McGregor's imagination too. The following year, he included the HON in an address he gave at MIT (McGregor, 1957a: 8):

Perhaps the best way to indicate why the conventional approach of management is inadequate is to consider the subject of motivation. In discussing this subject, I will draw heavily on the work of my colleague, Abraham Maslow of Brandeis University. His is the most fruitful approach I know. Naturally, what I have to say will be overgeneralized and will ignore important qualifications, in the time at our disposal, this is inevitable.

In September 1957, McGregor wrote to Maslow again, enclosing a copy of his MIT address, expressing his hope that Maslow would approve of the way he had used the HON, and asking if there was further research support for self-actualization beyond what had appeared in Motivation and Personality (McGregor letter to Maslow, September 26, 1957 Maslow Papers M397). Maslow told McGregor he had done "a very fine job" and promised to send him all his recent papers (Maslow letter to McGregor, October 9, 1957, Maslow Papers M397). It is not clear if these papers were sent; in any event, Maslow had not done any further research, because by this time he had lost interest in empirical research. Others could do the empirical tests if they wished, but he

\footnotetext{
${ }^{2}$ It has been believed that it took nearly 15 years from the 1943 paper in Psychological Review for Maslow's theorizing to appear in the management domain. However, a chapter by McGregor in Hoslett's (1946) Human Factors in Management reveals that McGregor was influenced by Maslow far earlier. The chapter is a reproduction of a paper McGregor published in Journal of Consulting Psychology in 1944 and shows the influence of Maslow's earlier work on human needs on McGregor's thinking about the dependence of subordinates on their superiors for the satisfaction of their needs.
}

saw that as a distraction from his role as the innovator and pioneer of new ideas (Hoffman, 1988).

An article based on McGregor's MIT address was reprinted in Management Review (McGregor, 1957b), a publication sent to all 30,000 members of the American Management Association (by far the largest management interest group at the time). For reasons unknown, however, the statement about Maslow inspiring Theory X and Y was omitted from the reprint, as was McGregor's comment about how he had overgeneralized Maslow's ideas. Although the paper drew heavily on the HON, there was no citation or reference to Maslow.

\footnotetext{
"For reasons unknown, however, the statement about Maslow inspiring Theory $X$ and $Y$ was omitted from the reprint, as was McGregor's comment about how he had overgeneralized Maslow's ideas.”
}

In his classic The Human Side of Enterprise (1960), McGregor did not reference Maslow's HON as he discussed the hierarchy, but he did include Motivation and Personality in a reference list at the end of Chapter 3 on page 44 . The book had a transformational effect on the nascent field of organizational behavior (or "human relations," as it was known then). Indeed, a survey of members of the Academy of Management in 1974 identified it as the most seminal contribution to the management literature (Matteson, 1974).

A close reading of The Human Side of Enterprise reveals the heavy influence of Maslow's thinking. McGregor's phrase "man is a wanting animal" (1960: 36) resembles Maslow's "man is a perpetually wanting animal” (1943: 370); and McGregor's "Man lives by bread alone, when there is no bread" (1960: 36$)$ is very close to Maslow's "It is quite true that man lives by bread alone-when there is no bread" (1943: 375). So, although it is generally held today that The Human Side of Enterprise "catalyzed Maslow's growing impact on business theorists and executives, and brought him fame" (Hoffman, 1999: 251), at the time of its publication, and for some time after, Maslow's influence was obscured. It is understandable, in this light, that Huizinga concluded in 1970 "that most people who cite Theory Y cite the hierarchy of basic needs as if it were a part of Theory $\mathrm{Y}$, and therefore omit to mention its real source" (1970: 54).

McGregor's incorporation of Maslow's thinking into his work in this obscure fashion facilitated later misinterpretations of Maslow and might have contributed to others placing the $\mathrm{HON}$ in a pyramid. For 
example, among the most popular criticisms of the hierarchy of needs today is the view that people are motivated to satisfy only one need at the time, that a need must be fully satisfied before they move to a higher level need on the pyramid, and that a satisfied need is no longer a motivator of behavior. This view is promulgated by McGregor, not Maslow. McGregor (1960: 39, emphasis in original) summarizes: "The man whose lower-level needs are satisfied is not motivated to satisfy those needs. For practical purposes they exist no longer."

Maslow (1943: 388) himself was clear that such a view would be a "false impression" of his theory. In explaining his need categories, Maslow presented extreme examples. For instance, a man who is starving is overwhelmed by the physiological need to satisfy his hunger: "such a man may fairly be said to live by bread alone” (p. 374). But he was quick to point out that such situations are rare-most people "are partially satisfied in all their basic needs and partially unsatisfied in all their basic needs at the same time" (p. 388). Maslow is adamant that "any behavior tends to be determined by several or all of the basic needs simultaneously rather than by only one of them" (1943: 390, emphasis in original). Acknowledging this nuance would make a ladder a more appropriate representation than a pyramid (if a geometric representation is necessary), since, as promoters of good design point out, a hierarchical triangle "promotes the presentation of levels that must be addressed separately before these are transcended and higher levels moved up to" (Lidwell, Holdon, \& Butler, 2003).

Another common critique of Maslow today relates to the pyramid's universalizing assumption that all individuals in all societies have the same needs arranged according to its hierarchy and are pursued in the same order. Once again though, although this assumption is promoted by McGregor's use of Maslow's ideas, it is rejected by Maslow himself. Maslow (1943: 387) acknowledged that while most of his clinical patients seemed to have their needs arranged in his needs hierarchy, there were "a number of exceptions." For some, self-esteem was more important than love. The most important exception was the "martyrs," who are prepared to sacrifice lower level needs in the pursuit of self-actualization. Maslow (1943: 390) was clear that "no claim is made that [self-actualization] is ultimate or universal for all cultures."

Yet another area of slippage between Maslow and interpreters concerns the labels given to each of the five need levels that are now understood to make up the pyramid. Table 1 compares those presented in Maslow's original 1943 paper, three editions of Motivation and Personality, McGregor's descriptions in his 1957 and 1960 publications, two contemporary books which discuss Maslow's legacy to management, as well as a small selection of top-selling management textbooks. Robbins et al.'s (2015) treatment is typical, with the third level being "social" needs. Their source is the 1987 edition of Motivation and Personality, but neither this edition, nor the two which preceded it, use this term. In Motivation and Personality Maslow added "belongingness" to "love" as the description of the third needs level developed in 1943, but he did not use the label "social." Similarly, Bateman and Snell (2009: 482) cited Maslow (1943) as the source of their pyramid, which has "social" and "ego" needsneither of which were used in that paper. McGregor, we suggest, is the likely inventor of these labels, since they appear in all published forms of The Human Side of Enterprise in 1957 and 1960.

\section{0s:}

Davis and McDermid, Pyramid Pioneers

Although McGregor did much to popularize Maslow's ideas in management, no pyramids or triangles appear in McGregor's works. The first published

TABLE 1

The Development of Maslow's Five Levels of Motivation

\begin{tabular}{|c|c|c|c|c|c|}
\hline Maslow (1943) & $\begin{array}{c}\text { Maslow (1954, } \\
\text { 1970, 1987) }\end{array}$ & $\begin{array}{c}\text { McGregor (1957a, } \\
\text { 1957b, 1960) }\end{array}$ & $\begin{array}{l}\text { McDermid } \\
\text { (1960) }\end{array}$ & $\begin{array}{c}\text { Stephens \& Heil (1998) } \\
\text { Maslow on Management; } \\
\text { Stephens (2000) } \\
\text { Maslow Business Reader }\end{array}$ & $\begin{array}{l}\text { Schermerhorn et al. } \\
\text { (2014); Robbins et al. } \\
(2015)\end{array}$ \\
\hline $\begin{array}{l}\text { self-actualization } \\
\text { esteem }\end{array}$ & $\begin{array}{l}\text { self-actualization } \\
\text { esteem }\end{array}$ & $\begin{array}{l}\text { self-fulfillment } \\
\text { ego }\end{array}$ & $\begin{array}{l}\text { self-realization } \\
\text { esteem }\end{array}$ & $\begin{array}{l}\text { self-actualization } \\
\text { esteem }\end{array}$ & $\begin{array}{l}\text { self-actualization } \\
\text { esteem }\end{array}$ \\
\hline love & $\begin{array}{l}\text { belongingness } \\
\text { and love }\end{array}$ & social & social s s s & social & social \\
\hline safety & safety & safety & safety & safety & safety \\
\hline physiological & physiological & physiological & physiological & physiological & physiological \\
\hline
\end{tabular}


FIGURE 1

An early rendition of Maslow's hierarchy of needs. From Human Relations in Business (p. 41), Davis, 1957. Reprinted with permission from McGraw-Hill Education.

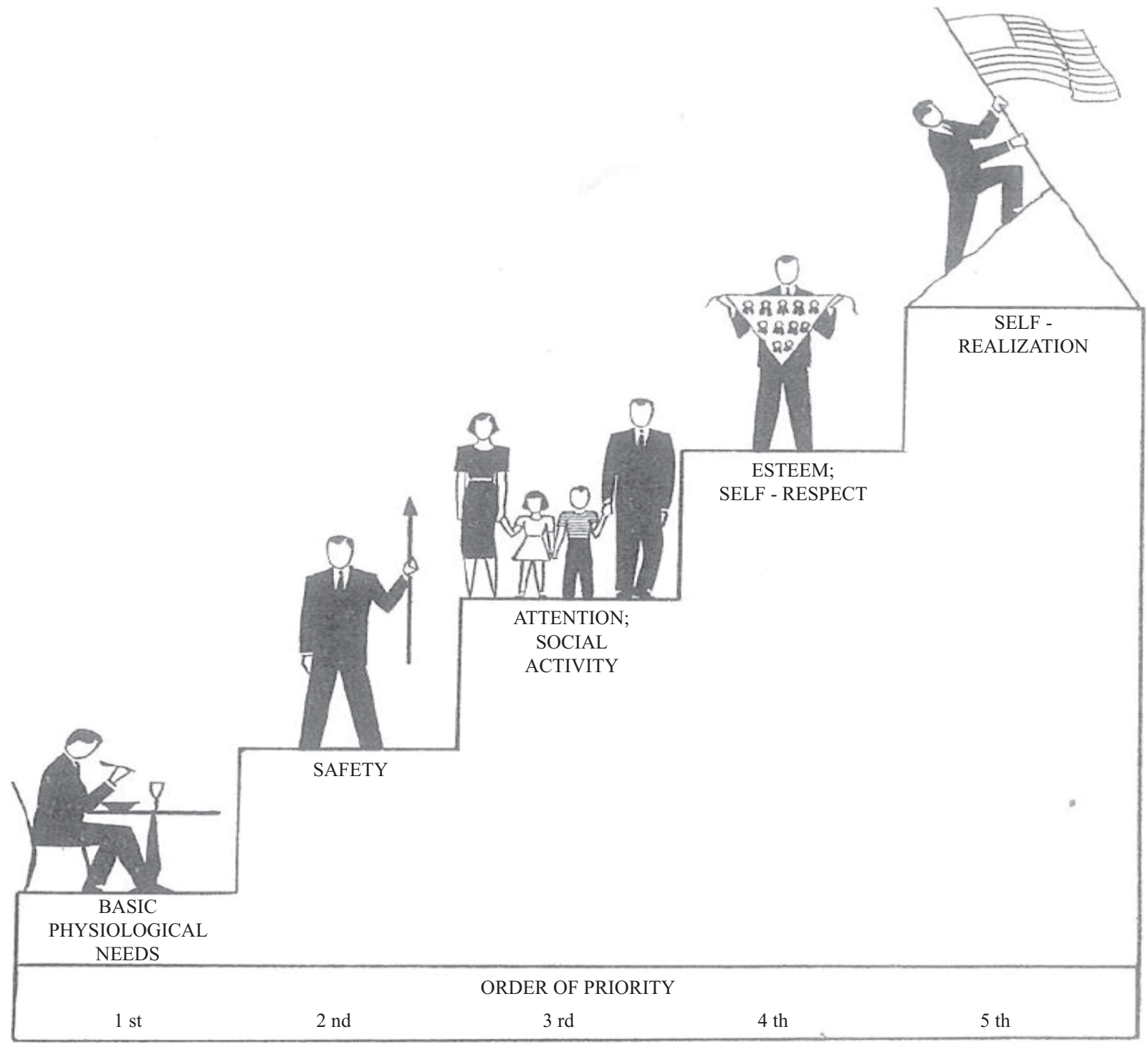

triangular representation of the HON we found was in Keith Davis's (1957) Human Relations in Business (see Figure 1). It is not an equilateral triangle as the pyramid will become, but a series of steps in a rightangled triangle leading to a peak. Davis would be unfamiliar to most scholars now, but he was active in the Academy of Management in the late 1950s, (eventually becoming its President in 1964), and at the forefront of discussions about the field's emerging status as a profession. He is described by management's most highly regarded historians as "Mr. Human Relations" for his profound influence on the emerging field (Wren \& Bedeian, 2009: 44). To elevate management's status within the university, Davis (1957) argued that the field needed to take the teaching of its history more seriously. To be respected outside the university, management academics needed to position themselves as experts (Davis, 1959). The triangular symbol that Davis created out of the HON addressed these issues: The triangle with steps captured the thinking of an important figure in the history of an established discipline of which management could claim to be a new branch. Additionally, it helped those sharing their expertise in industries with an easily applicable model. Davis's addition of the specifically business-attired White 
FIGURE 2

Probably the earliest published rendition of "Maslow's Pyramid." (@Elsevier. Reprinted with permission from C. D. McDermid, 1960. "How money motivates men," Business Horizons, 3(4): 94.)

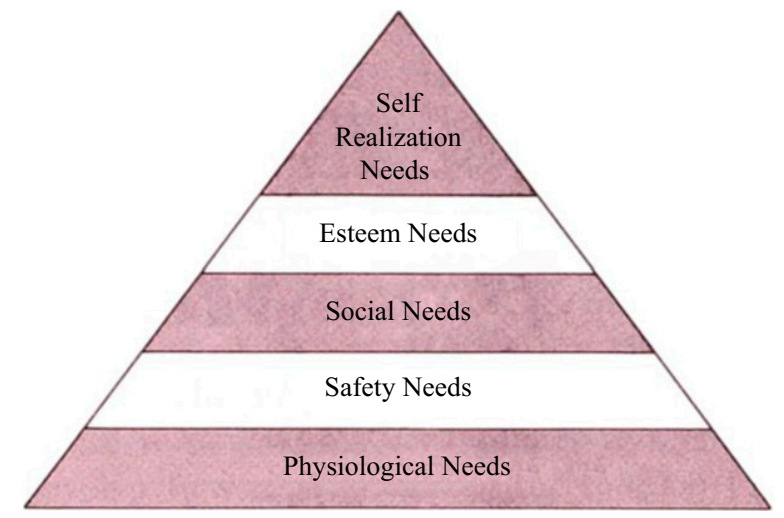

executive (Maslow's idea was a theory of motivation for all people), prefigured the HON's importation into the corporate world of the 1960s. It was clearly pitched for the American market too, as the flagraising is reminiscent of the famous image of the flagraising on Iwo Jima (Cooke \& Mills, 2008).

Although Davis did not invent the pyramid that we associate with the HON today, it appears his stepped diagram was the inspiration for what appears to be the first rendition of the pyramid. This appears in Charles McDermid's article, "How Money Motivates Men," published in Business Horizons in 1960 (see Figure 2). ${ }^{3}$ McDermid was a consulting psychologist for the firm Humber, Mundie, and McClary. Because "maximum motivation at lowest cost is the desired end result," McDermid (1960: 98) advised managers to use Maslow's theory of motivation, which "can be arranged" as a pyramid (p. 94) to evaluate the needs of their employees and adjust compensation packages accordingly. Although McDermid did not cite Davis in any way, that he does not use "self-actualization" (the term used by Maslow), or McGregor's "self-fulfillment, but "self-realization" (the term that Davis had substituted), suggests that Davis's interpretation influenced McDermid's ideas.

McDermid's was not the first attempt to develop an easy to remember and easy to apply motivation

\footnotetext{
${ }^{3}$ In the 1960, 70s, and 80s, Business Horizons was often a medium for promoting popular new management ideas and frameworks. For example, it was the first forum for publicizing both the notion of a "matrix organization" (Galbraith, 1971) and McKinsey's Seven-S model (Waterman, Peters, \& Phillips, 1980).
}

framework for managers. A year earlier, Robert K. Burns (1959: 123, emphasis in original) published a similarly oriented paper in Public Personnel Review, with a typology of needs and a catchy phrase: "Taken together the first letters of these four needs-security, opportunity, acceptance, and recognition, spell soarwhich is what happens to the motivation of men if these needs are met on the job." But it was the pyramid, not Burn's acronym that took flight.

\section{0s and 80s: More Science, More Textbooks}

In this section, we discuss two main factors that helped Maslow's HON in pyramid form grow in the consciousness of those studying management. First, the 1960 s and 70 s brought a wave of serious researchers seeking to study management scientifically with a testable theory, one that appeared to fit well with the most common object of their inquiries: people in large hierarchical organizations. Second, in the 1970s and 1980s, Maslow's Pyramid was just the kind of content for which the first editions of many of the most popular modern management and organization textbooks were looking.

Although Maslow himself was not interested in testing his theory empirically, a number of scholars in the field of human relations were. This was a time when the recommendations of two important studies on the future of management research and education where still fresh. A report from the Carnegie Foundation argued that business schools must pursue the development of a "systematic body of knowledge of substantial intellectual content ... in the form of a set of business sciences" (Gordon \& Howell, 1959: 71-72). Likewise, a report from The Ford Foundation identified the need "for research which meets high scientific standards" (Pierson 1959: xv). Maslow's thinking provided what looked like a testable scientific theory in human relations at a time when there were few to be found.

Pioneering organizational behavior scholars such as Clayton Alderfer (1989: 358) wrote of his "intense excitement" when he read the first edition of Motivation and Personality, "as if a new light had been turned on to illuminate human motivation." Certainly, this is how Maslow's ideas were marketed to management scholars. On the crest of a wave of popularity, as Maslow was introduced to the fledgling field, he produced a book, Eupsychian Management (1965). This book with a strange name and somewhat rambling thoughts was created from transcribed tape-recorded journal entries Maslow made in the summer of 1962 while a visiting fellow at 
Non-Linear Systems in Del Mar, California. Warren Bennis, who wrote the Foreword for the book, described it as "an outlet for an experiment in truth, an opportunity to test hypotheses, even seemingly outrageous ones" and "a sketch-pad for his unfinished, and possibly, most creative work" (1965: vii).

Those who put the HON to the test throughout the 1960s and 70s greatly appreciated Maslow's creation of a new field of research with his theory that behavior was not just the result of unconscious desires, as the psychoanalysis conceived, or shaped by rewards and reinforcement, as the behaviorists had imagined, but was also driven by the desire to fulfill internal needs. Subsequently, scholarly articles such as "An Empirical Test of a New Theory of Human Needs" (Alderfer, 1969); “An Examination of Maslow's Need Hierarchy in an Organizational Setting” (Hall \& Nougaim, 1968); and "A Study of the Perceived Need Satisfactions in Bottom and Middle Management Jobs" (Porter, 1961) tested HON-based hypotheses.

McGregor's former student, Chris Argyris, also played an important role in applying Maslow's theory about individual motivation to life in 1960s organizations. His book, Integrating the Individual and the Organization (1964: 32), promoted an "oversimplified model of Maslow's concept" with lower and higher level needs. Argyris saw "modern industrial societies" generally having taken care of lower level needs, where this was not the case in "undeveloped societies." Lower level needs relate to "organizational activities at the lowest level." He wrote that rewards related to selfactualization "tend to exist primarily for the upper levels of management, for researchers and some engineers, and some sales people" (1964: 32, 37, 255).

Although an increasing number of empirical studies (e.g., Alderfer, 1969; Lawler \& Suttle, 1972; Payne, 1970) failed to confirm aspects of the HON, management researchers were reluctant to dispense with it, concluding that failure to confirm was probably more a product of deficiencies in the research than with the theory itself. Moreover, it is probable that senior executives who were providing research access and other resources for this kind of empirical research at this time would have found agreeable a theory that implied those at the top of the hierarchy had reached a more advanced state of human development (Cullen, 1997). In any case, this was a time when pyramids were a popular way of representing management challenges. The structure and dynamics of bureaucracy were capturing the attention of social scientists (e.g., Blau, 1956) at a time when management consulting firms such as McKinsey \& Co, Bain and Company, and the Boston Consulting Group were competing to woo clients with new management ideas. Problems of poor organizational performance were diagnosed as a lack of control, and the prescriptions administered came in the form of detailed job descriptions, rules, procedures, committees, and a carefully mapped out chain of command expressed in pyramid form (O'Shea \& Madigan, 1997). Elsewhere, Chandler (1962: 1) was developing a new subfield, strategic planning, by defining the object of inquiry as what happens at the highest level of a pyramidal hierarchy. The consultants were in the business of building and selling pyramids. It was not a big leap to suggest that just as high-performing organizations at this time could be represented as pyramidal hierarchies, so too could their employees.

\section{"The consultants were in the business of building and} selling pyramids."

By the late-1970s, however, management researchers were starting to lose faith in the HON. Wahba and Bridwell's (1976: 234) meta-analysis of 10 studies investigated the theory's empirical validity and concluded it was "almost a nontestable theory" because of Maslow's lack of rigor, loose language, and vagueness in conceptualizing his ideas (see Salancik \& Pfeffer, 1977, for a similar assessment). But by the time these criticisms started to gather momentum, another vehicle for promoting Maslow's Pyramid had emerged: the modern management textbook.

Most of the best-selling management textbooks of today were first published in the late 1970s and early 1980s (e.g., Baron, 1983; Robbins, 1979; Wheelen \& Hunger, 1983). Although there had been some management textbooks before (e.g., Davis, 1957), factors emerged to change the management textbook industry. In response to the Carnegie Foundation and Ford Foundation reports of 1959, management scholarship was becoming more scientific and quantitative. Its insights were not in a form easily digestible by students. As Hunger and Wheelen (1980) reported on their survey of management educators: "Most [respondents] took the stance that schools have gone too far with quantitative methods [and] modeling [and] felt it was time to return to the teaching of more practical skills and techniques" (p. 29). The number of students studying business subjects at universities was growing, and advances in publishing technology enabled a new kind of textbook that occupied a middle ground between being practical and maintaining academic credibility. In the preface of one of his popular books, Stephen Robbins described 
what was to follow as the "culmination of what I've learned works and doesn't work in the teaching of the basic course" (1984: xviii). Among the list of features he identified as being different from textbooks that had preceded were "pragmatism"-students wanted useful knowledge-and "figures and exhibits," which were useful aids, he claimed, in the learning process.

In these new textbooks, the subject of management was divided into discrete chapters: (e.g., motivation, organizational design, managing change), and in each subfield different theories and ideas would be presented, generally chronologically, to show the progression of that subfield. Each chapter would also include exercises or case studies where students could test their knowledge by applying the theories and frameworks. Diagrams, particularly ones divided into steps like Maslow's Pyramid, made the subject look practically applicable and the knowledge easily testable. To this day the pyramid stands tall as a foundation stone in any textbook chapter on motivation.

\section{0s-Today: The Perpetual Power of the Pyramid}

As empirical studies have continued to shed doubt on the validity of the HON, related critiques about the presentation of Maslow's Pyramid have increased (Fineman \& Gabriel, 1994; Watson, 1996; Dye et al., 2005; Mills et al., 2005). So, why does Maslow's Pyramid and the HON theory that it purportedly represents continue to prevail and be so prominent in our teaching? We believe it has much to do with the power of the geometric form that Maslow never promoted, and whose characteristics he actively argued against.

Although the meaning of shapes has not been studied in relation to management theories, researchers in graphics, branding, and traffic-sign design have determined that using geometrical forms to frame, order, and present ideas can have powerful effects (Macnab, 2008). For nearly 100 years, advocates of Gestalt theory have explored how viewers group together different objects into groups or a single coherent whole when the separate elements are arranged together in a particular way. Research has concluded that the arrangement of elements follows principles of similarity, continuation, closure, proximity, figure/ground relations, and symmetry and order. Elements so arranged feel more connected, coherent, and complete (Arnheim, 1954).

The arrangement of the HON into a simple graphic gives it an appearance of coherence and completeness. Moreover, presenting the $\mathrm{HON}$ as a pyramid or equilateral triangle on its base conveys specific characteristics that may be well suited to management and corporate audiences. Pyramids and equilateral triangles are the most difficult straight-sided shapes to break or bend; thus, they represent power and strength (Newman, Garry, Bernstein, Kantner, \& Lindsay, 2012). Also, pyramids convey religious significance, reflecting a pathway from earth to heaven or describing powerful trinities, such as body-mind-spirit or father-son-holy ghost or past-present-future. They also indicate scientific credibility, universality, and precision. An upright triangle illustrates an objective view, and its geometry conveys exactitude.

The triangle's ability to point in a single direction explains the Greek symbol delta $(\triangle)$, meaning change. By suggesting change, action, and conflict, triangles capture attention and put people on alert. Traffic signs that indicate hazards tend to be upright triangles. Conversely, because triangles resting on a point rather than a base have been proven to illicit feelings of conflict, tension, doubt, nervousness, risk, a focusing of the mind, and looking downward, they are ideal for "Yield" or "Give Way" signs (Armbruster, Suchert, Gärtner, \& Strobel, 2014; Larson, Aronoff, \& Stearns, 2007). ${ }^{4}$

In many cultures, triangles represent masculinity (a triangle standing on its base like a pyramid signifies male, whereas one standing on its tip signifies female). It is a symbol of energy (a triangle on its base signifies fire) and reflects inspiration and aspiration. As stated by Macnab (2008: 201), "the triangle is the symbol of inspiration through the transcendence of a mundane base. The divisive line at the bottom of the triangle returns to its divine origins, the point of infinity and wholeness." This symbolism encouraged Adidas to develop its traditional three stripes logo into the form or a pyramid (Wang, 2015).

In the age of teaching with PowerPoint, Maslow's Pyramid went on to become a staple in the slide packs (often developed in tandem with increasingly glossy and graphic-rich management textbooks). Indeed, experts claim that the layered pyramid is an exemplar shape for anybody looking to design an effective presentation that organizes information from the greatest to the least (McGuire, 2019). The pyramid has gained further power as it has extended beyond management writing and teaching to become

\footnotetext{
${ }^{4}$ One writer who investigated the origins of Maslow's ideas concluded that Maslow based his triangle on the tipi of First Nations people the Blackfoot, following a summer Maslow spent with the tribe in 1938 (Michel, 2014). However, in Blackfoot tradition, the triangle rests on its tip, not its base, which would be detrimental to Maslow's $\mathrm{HON}$ as a reassuring and popular theory for managers.
} 
part of the modern fabric of life and pop-culture. Searching Maslow's Pyramid reveals dozens of versions and reinterpretations of the form: pyramids that outline five levels of robot needs, vampire and zombie needs, and Internet needs (with Wifi generally being seen as a base need without which young people can no longer function on any other level). There is even a Maslow Hotel in Johannesburg, dedicated to the HON, with its levels of accommodation arranged in pyramid form. ${ }^{5}$

Following World War II, Maslow's HON captured the prevailing ideologies of individualism, nationalism, and capitalism in America and justified a growing managerialism in bureaucratic (i.e., layered triangular) formats (Cooke \& Mills, 2008; Cooke et al., 2005; Cullen, 1997; Dye et al., 2005). But Maslow's HON may be the only management theory that has "gone viral" and become a meme, and it is doubtful that this would have happened if it did not come packaged in a pyramid with five clear categorical levels. Although it may be difficult to prove links between the pyramid shape and the HON's prominence, no other management theory has been so closely linked to a particular geometric symbol (Clark, 2012; see also Peterson \& Park, 2010). Repetition in this form has not only strengthened misconceptions of Maslow's HON, but also made it (and our misconceptions) more ubiquitous, more ingrained, and harder to change (De Bruyckere et al., 2015).

\section{PYRAMID SCHEME: WINNERS AND LOSERS}

Our investigations into how Maslow's Pyramid became not just the most famous symbol in management studies, but a meme, raise broader questions about how management knowledge has developed through the field's history, as well as questions about how we, as management educators, pass on that knowledge to students. These questions concern the politics of knowledge, especially the interests that are served by ideas being presented in particular ways. Presenting the HON as a pyramid suited almost everyone involved: consultants like McDermid who needed a memorable framework to sell to clients; the Academy of Management who wanted its members to be seen as being relevant to practice;

\footnotetext{
${ }^{5}$ The Hotel "aspires to create an environment that optimally satisfies the fundamental needs of the individual so that the mind is free to achieve its highest potential, selfactualisation." https://www.suninternational.com/maslow/ stories/business/how-maslow-got-its-name/
}

textbook publishers and authors who needed not just an idea that had practical applications to the "real world," but also the academic credibility that a "founding father" such as Maslow could provide (and then a progression that could be demonstrated by showing his ideas to be simplistic and outdated); and researchers who could propose extensions to the pyramid to address gaps in Maslow's thinking.

It also suited Maslow. This distinguishes the pyramid from other examples of misrepresentations within management studies of famous historical figures, such as Smith, Weber, and Lewin, who died well before their ideas were appropriated by others. Maslow lived for 10 years after McDermid's presentation of the pyramid and did little to correct it, despite expressing in his writing a dislike for reductionism, or what he called rubricizing: "a cheap form of cognizing, i.e., really a form of not-cognizing, a quick, easy cataloguing whose function is to make unnecessary the effort required by more careful, idiographic perceiving or thinking” (Maslow, 1962: 126).

Maslow's personal journals (1979a,b), which he began writing in 1959 and detail his inner thoughts, emotions, and conflicts, are revealing. By the time the HON was beginning to be celebrated by McGregor, Davis, McDermid and others (Haire, 1956; Pellegrin \& Coates, 1957), aspects of Maslow's professional life were unraveling. He felt underappreciated in psychology, whose journals had been taken over by experimental studies, which depressed Maslow for their lack of creativity and insight. He also had more pragmatic concerns, suffering periods of ill health and financial difficulties. Maslow found personal and professional redemption in his acceptance in the management community and financial gain through speaking engagements and consulting. He welcomed the new field showing an interest in his ideas and offering the potential for personal benefit. It is not surprising then that he would let the reinterpretation and simplification of his ideas by his admirers pass.

However, while some benefitted from the creation of Maslow's Pyramid, not everyone did. The biggest losers, we suggest, have been management students. We identify three specific negative effects in this regard: (1) that the pyramid is a poor representation of Maslow's HON; (2) that the preoccupation with the pyramid obscures the context within which the theory was created; and (3) that by focusing exclusively on the pyramid, we miss the other contributions that Maslow's thinking can make to management studies.

The first problem with Maslow's Pyramid is that it is plainly wrong, not so much because he did not create it, but because a pyramid-although a good fit for a 
universal and aspirational theory containing a rigid hierarchy of mutually exclusive categories-is a poor representation of Maslow's original thesis on motivation. A rectangular shape like the ladder that many used before the pyramid became de rigueur (e.g., Porter, Lawler, \& Hackman, 1975; Wren, 1972), would be a more accurate representation of his 1943 conception. A ladder addresses the "narrowing" elitism of the pyramid and its implication of a definite end-point to the progress of human development, rather than allowing for the possibility of "steps" beyond selfactualization (Rowan, 1998; Wilber, 2000). The ladder also attenuates the most common misrepresentation of the HON: that people occupy only one level at any particular time. The depiction of the HON as a pyramid, with horizontal lines demarcating the different levels, makes it difficult to imagine that people can be simultaneously striving to satisfy a number of different needs. When one is on a ladder, multiple rungs are occupied by the feet and hands, and other rungs may be leaned on as well. The ladder as thus described is far closer to Maslow's original thinking.

Moreover, a ladder better denotes movement both up and down the hierarchy, another overlooked feature of Maslow's theory. As prominent management historian Daniel Wren (1972: 329) noted in the first edition of his The Evolution of Management Thought: "In Maslow's theory, people moved up the ladder of needs as each level was satisfied [but] they could [also] move in a reverse direction if fulfilment of a lower order need was threatened or removed." Indeed, Wren continued to use the ladder to describe the HON until the most recent, 6th edition (Wren \& Bedeian, 2009). Removing the pyramid from management textbooks and replacing it with a ladder would be a step forward.

This leads to our second problem with the pyramid, which is that it is presented as a simplistic "cookie cutter," one-size-fits-all approach to managing people, and not at all what Maslow intended. The case of Maslow's Pyramid is representative of the way historical figures in management studies and their ideas are presented, frozen in time and devoid of their historical context (Cooke et al., 2005; Dye et al., 2005; Hassard, 2012; Jacques, 1996; Genoe McLaren, Mills, \& Weatherbee, 2015). Although the potted histories of management that often occupy "chapter 2" of introductory textbooks are criticized for their oversimplification (Jacques, 2006; Jacques \& Durepos, 2015), at least Frederick Taylor and his scientific management are to some extent situated in events of the day, to give students insight into the reasons for their emergence and spread. In contrast, Maslow's
HON almost always appears in chapters on motivation and with little or no discussion of context.

While today's textbooks judge the HON harshly against the criterion of scientific validation, understanding the context could lead to a more sympathetic, and more informed assessment. Maslow was an eminent psychologist: President of the American Psychological Association, the founder of humanistic psychology, and an intellectual. He was not a management scholar or consultant, nor did he desire to be. Maslow was watching the world go to war for the second time in 30 years, and he believed his field of psychology could contribute an understanding of its causes, were it not for its scientific conservatism and preoccupation with method. Paradigm shifts in thinking would only result, he believed, from a more creative, risk-taking approach, for which his HON stands as an exemplar (Lowry, 1973: 47). At the time, Maslow's efforts to break free from the straight-jacket of empiricism were well-received. Two years before his classic 1943 article in Psychological Review, Maslow published a paper in the same journal on the principle of frustration, which would become a cornerstone in his motivation theory. Klein (1942) described it as "a superb example of sound armchair psychology” (p. 233) and said Maslow had proved that psychologists need not be "concerned about being stigmatized as philosophers" (p. 233) and "need no longer worry about the feelings of inferiority of our psychological forbears because of the greater precision and rigor of the natural sciences" (p. 233).

Is a more context-sensitive depiction of Maslow's HON in management textbooks realistic? After all, are textbooks not forced to be reductive to provide students with a broad understanding of the field's foundations? Although this argument has intuitive appeal, the existence of textbooks that provide a more sophisticated, context-rich account of the HON and other aspects of Maslow's theorizing (e.g., Clegg, Kornberger, \& Pitsis, 2016; Mills et al., 2005) demonstrate that it can be done. But it also raises the question of whether textbooks are sufficient to deliver the basics of management education, even for introductory courses. Why not also get students to read original sources, which is common practice across the social sciences? After all, compared with academic journals of today, where papers are often written in a style impenetrable to all but a small number of "insiders," the writings of historical figures such as Taylor, Lewin, and McGregor are accessible and digestible even by new undergraduates.

In the case of Maslow, this would be revealing. Students would see that he anticipated criticisms 
that textbooks would later make of his theory and explicitly cautioned against his ideas being interpreted in these ways. Maslow did not say that the HON is unidirectional, that achieving higher levels makes you a superior being, that once a need is satisfied it no longer affects behavior, or that it applies to all people in the same way (Maslow, 1943, 1954). It would be clear to students that Maslow's theory in his writings is more sophisticated and nuanced than the simplistic HON presented in most textbooks.

This connects with our third problem with the pyramid: Its symbolism and memorability prevent us from looking beyond it in intellectual terms to create a new Maslow for management studies. If students read Maslow in the original, they would realize that he was writing about human needs, not organizational needs. He was not writing a guide for managers in organizations, but about people as individuals and how societies diminish individual creativity. His work was about freedom of inquiry and expression, which were among the necessary preconditions Maslow stated for the satisfaction of human needs. Maslow was about individual growth and fulfillment, knowing yourself, and reaching your potential.

In the 1950s, creativity and its barriers became increasingly topical, partly because of the Soviet Union's space program successes (Hoffman, 1988). This is in part how Maslow made his reputation beyond the academy. Following the publication of Motivation and Personality in 1954, he emerged as one of the few established psychologists to challenge the prevailing conformism of the 1950s and speak out on how large organizations and social conformity stifled individual self-expression. In a 1958 lecture he observed that "[a] first rate soup is more creative than a second rate painting, and that generally, cooking or parenthood or making a home could be creative while poetry need not be" (Maslow, in Covin, 1974: 108). One need not strive to get to the top of an organization to be fulfilled-in fact such striving might be detrimental to one's existence as a creative being.

This is not the only way in which Maslow was opposed to modern management conventions. In Eupsychian Management, he revealed his frustration that organization theorists, including Schein and McGregor, were seeing his theory of human nature as a means to a financial end-short-term profitsrather than the end which he saw, a more enlightened citizenry and society (1965: 240). Few managers or organization theorists, he complained, "have the courage to think in far terms, in broad- range terms, in utopian terms, in value terms" (1965: 40). Motivating employees to be more productive at work was not the end that Maslow desired for the HON.

He would later seek to correct this deficiency himself, with his unfinished conceptualization of Theory $\mathrm{Z}$ in which he postulated that people, once economically secure, would strive for a creative and productive work life that could satisfy higher level needs (Maslow, 1998). This blurred the boundaries between "work" and "life" in many ways, prefiguring subsequent workplace initiatives where work is seen as an integral part of life. But Maslow died before finishing his work on Theory Z (Hoffman, 1999). Regrettably, the pyramid became Maslow's major legacy to management studies.

These three problems and the losses they inflict are significant and relate not just to Maslow. A reductionist, superficial, and often misleading coverage of key ideas in management studies, typical of the best-selling, most influential, largely U.S. textbooks, does not serve our students well. Therefore, it would be worthwhile as management educators to reflect critically on what we are trying to achieve in our introductory courses in management, as they provide lasting first impressions of the field that students carry through their careers (Christopher, Laasch, \& Roberts, 2017).

\section{BEYOND THE PYRAMID: IMPLICATIONS FOR MANAGEMENT EDUCATION}

"I would like to believe that various kinds of experi-
ences and decades of academic research would ex-
pand our knowledge base. So it is sometimes a bit of a
shock to see how much we thought we already knew
50 years ago and how little our conclusions have
changed in the field of social/organizational psy-
chology since then."

Ed Schein (2015: 7-8)

Having shown the pyramid to not be Maslow's creation, what should we do? Some writers, reflecting on the criticisms leveled at Maslow but still enamored with the pyramid, have argued that we should update, refurbish or "renovate" it for a new world (Kenrick et al., 2010; Schaller et al., 2010). Some consider the HON fatally flawed, but note that "old theories, especially intuitive ones, die hard" and retain it to highlight how new theories of motivation build upon the old (Robbins \& Judge, 2015: 218). A few have suggested that the HON should be 
excluded from new editions of textbooks (Kremer \& Hammond, 2013). This is not what we are recommending.

We argue that the popularity of the pyramid obscures a more significant problem. Reflecting on his more than 60 years of publishing, Ed Schein raised doubts about whether his field has progressed as far as we might wish to believe, suggesting the enormous growth in research might be obscuring insights we learned decades ago, rather than providing new ones. With growth has come fragmentation with jargon-laden subfields that rarely communicate with each other and produce research dominated by "quantitative abstraction" (p. 3). Concurrently there has been a proliferation of surveys, models, and instruments developed by consultants and practitioners that focus on improving organizational performance, but their work has little connection to the academic research we produce (Schein, 2015).

If a leader in our field like Schein has openly questioned our progress, then perhaps we should listen and engage the issue. We need better awareness, evaluation, and integration of historical writings relevant to management. We need an appreciation of insights from the time before empiricism dominated research and the modern textbook dominated teaching.

Although we have argued that presenting Maslow's HON as a ladder would be a better representation of his theory, we should not need a ladder, pyramid, or any other symbol to generate insights from Maslow's thinking on the nature of human needs. Maslow's currency was words, not figures and diagrams, and is a valuable reminder that not all good ideas come in the form of a memorable symbol or $2 \times 2$ matrix. We encourage a "restoration" of Maslow's original thinking, rather than the "renovation" of the pyramid. Restoration would include encouraging people to read the original source of the HON, Maslow's 1943 article, rather than relying on far-removed secondary, even tertiary, interpretations that misrepresent Maslow's more nuanced insights.

We also advocate introducing students to the breadth of his thinking beyond the HON. They would benefit from understanding that his academic writing spanned nearly 40 years, across the most tumultuous period of the 20th century that included economic depression, war, and social movements for equality and justice. As Alderfer has noted (1989), Maslow's thinking shifted as he sought explanations for these events, and also for what was happening in his own life as a scholar, father, and husband. The simplification of his HON into the pyramid perpetuates a simplistic view of a complicated man and misunderstandings of his writings (Cooke \& Mills, 2008; Cooke et al., 2005; Dye et al., 2005; Mills et al., 2005).

In addition, the story of Maslow's Pyramid should cause us to reflect on how the forms used to communicate ideas and theories convey meanings that may change the nature of those theories, or promote perspectives inconsistent with those theories. For example, presenting strategic thinking as coming from those at the tip of the organizational triangle may lead to undervaluing the contributions that may come from other stakeholders. Likewise, presenting a model of change management in a linear step-by-step diagram may suggest a process far more simplistic than reality, leading to disappointing results (Cummings et al., 2016). Hence, we should consider whether the benefits of a memorable image in a PowerPoint outweigh the potential oversimplification or misrepresentation of what is being taught, and seek to manage this balance (Kaplan, 2011; Knight, Paroutis, \& Heracleous, 2017).

Beyond this, there is value to be gained by giving students an appreciation of how the subject of management studies has formed, through interactions among researchers, educators and consultants, practitioners, philanthropic foundations, and governments. All played a role in the creation and popularization of Maslow's Pyramid. Gaining insights into these processes can stimulate students' critical thinking. The history of the pyramid and Maslow's theory could be a powerful case study, because most students will have previously encountered "Maslow's Pyramid" and taken it as a given. As a case study, it would have the greatest value in an introductory course where it could help develop and further the critical thinking skills of future managers.

In exploring Maslow's wider contribution, management educators and students will need to wrestle with another dilemma: Maslow has been criticized for elitist, sexist, racist, and biological determinist views, as well as his stance on the Vietnam War (Cooke \& Mills, 2008; Cullen, 1997; Grant \& Mills, 2006; Knights \& Willmott, 1974/75; Prichard, 2002). Many of his ideas were not fully formed (as he acknowledged throughout his career) or even well thought-through. However, we should be wary of judging Maslow through the lens of today's values (Dye et al., 2005), but we should at the same time recognize that a number of his ideas about race, gender, and a biological elite were offensive when he said them and remain so today, leading many in the scientific community, such as Carl Rogers, to distance themselves from him (Hoffman, 1988: 298). 
However, to discard Maslow completely would be a loss, because he really did practice the free and creative thinking that he believed society needed, and what Schein (2015) suggested is largely absent in academia today. As such, Maslow still offers "a rare opportunity to observe a fertile and imaginative mind at work unfettered by the conventions of scientific reporting” (Vroom, 1967: 97). Maslow's original question that spurred his motivation theory was not "how can managers motivate workers to maximize productivity and profit" (as one might believe when seeing the pyramid in management textbooks and used as a consulting tool), but "what do we need for happiness and fulfillment in life" (Hoffman, 1988: 137). The test of enlightened management, he believed, was the effect of organizational policies on people's behavior outside of work, in the community. Inspiring the study of management and its relationship to creativity and the pursuit of the common good would be a much more empowering legacy to Maslow than a simplistic, 5-step, one-way pyramid.

\section{CONCLUSION}

The creation of Maslow's Pyramid has implications that go beyond a concern with his potential contribution to our field. It has implications for how we understand our field's historical foundations, and how those foundations shape our conception of what management is, what it could be, and how we teach our students as a result.

Consequently, what we advocate here is a criticalhistorical approach to both research and teaching. Fundamentally, this means moving beyond the idea that the reason for examining management history is to get an understanding of what happened in the past, or to download the "file" that is contained in chapter 2 of management textbooks (Wren, 2002). It means seeing history as a narrative that can interpret past events in many different ways, depending on the perspectives taken and the values underpinning them.

Many, if not most, of management studies' foundational ideas have been adapted from other disciplines, such as social psychology and economics, with these ideas filtered through our field's longstanding commitments to free-market capitalism, managerialism, organizational hierarchies, and the primacy of the individual. Acknowledging that historical interpretations are socially constructed and reflect deep-seated value commitments (Gergen, 1973), opens up the possibility for creating new histories of management from different perspectives. It also demonstrates that the narrow view presented in conventional histories of management need not limit us, but instead, we can create new and informative histories of our field-based on different events, times, people and places than have dominated to date.

This recognition can spur those interested in revisiting historical foundations and rethinking our field's past and future. With regard to research, this may involve going into the archives, reading the work of foundational thinkers in their original form, locating their contribution to our field within the body of their whole work and within the historical context, and comparing the presentation of their ideas in their home discipline alongside how they are presented in management studies. Or, it may involve looking at the forgotten roles played by those who currently do not populate management histories, such as women and non-European ethnic groups (e.g., Prieto et al., 2017; Cooke \& Alcadipani, 2015). These approaches can help us overcome what has become a very stale orthodoxy that simplifies the past and limits future perspectives and developments (Cummings \& Bridgman, 2016).

A critical-historical approach may also change how we teach management. As we have argued through our study of Maslow here, our textbooks could do a better job of representing the past. We need to encourage our students to think of management history as something that exists beyond the "chapter 2" of their introductory textbooks, while we rewrite these textbooks. But the change should be deeper than this. Fostering a critical-historical philosophy can help students to think creatively, a skill that students must develop to fulfill their potential in their future careers (Cummings, Bridgman, Hassard, \& Rowlinson, 2017). Studying the history of management today need not, and should not, be about the memorization of facts. It should foster thinking critically about how conceptions of our field's theories, like Maslow's Pyramid, have come to be, how the past could provide us with different foundations if we adopted alternative perspectives, and consequently, how we can create different conceptions to guide us into the future.

\section{REFERENCES}

Alderfer, C. P. 1969. An empirical test of a new theory of human needs. Organizational Behavior and Human Performance, 4: 142-175.

Alderfer, C. P. 1989. Theories reflecting my personal experience and life development. The Journal of Applied Behavioral Science, 25(4): 351-365. 
Argyris, C. 1964. Integrating the individual and the organization. New York: Wiley.

Armbruster, D., Suchert, V., Gärtner, A., \& Strobel, A. 2014. Threatening shapes: The impact of simple geometric configurations on peripheral physiological markers. Physiology \& Behavior, 135: 215-221.

Arnheim, R. 1954. Art and visual perception: A psychology of the creative eye. Berkeley, CA: University of California Press.

Ballard, J. A. 2006. The diffusion of Maslow's motivation theory in management and other disciplines. Paper presented at the Academy of Management Annual Meeting, Atlanta.

Ballard, J. A. 2015. Decoding the workplace: 50 keys to understanding people in organizations. Santa Barbara, CA: Praeger.

Baron, R. A. 1983. Behavior in organizations: Understanding and managing the human side of work. Boston: Allyn \& Bacon.

Bateman, T. S., \& Snell, S. S. 2009. Management: Leading \& collaborating in a competitive world (8th ed.). Boston: McGraw-Hill.

Bennis, W. 1965. Foreword. In A. Maslow (Ed.), Eupsychian management: viii. Homewood, IL: Richard D. Irwin, Inc. \& The Dorsey Press.

Blau, P. M. 1956. Bureaucracy in modern society. New York: Random House.

Burns, R. K. 1959. Management and employee motivation. Public Personnel Review, 1(April): 122-127.

Chandler, A. D. 1962. Strategy and structure: Chapters in the history of the American industrial enterprise. Cambridge, MA: MIT Press.

Christopher, E., Laasch, O., \& Roberts, J. 2017. Pedagogical innovation and paradigm shift in the introduction to management curriculum. Journal of Management Education, 41(6): 787-793.

Clark, D. 2012. Maslow (1908-1970) Hierarchy of needs. 5 or 7 levels? Useful or useless? Retrieved from http:// donaldclarkplanb.blogspot.co.nz/2012/04/maslow1908-1970-hierarchy-of-needs-5.html

Clegg, S. R., Kornberger, M., \& Pitsis, T. 2016. Managing and organizations: An introduction to theory and practice (4th ed.). London: Sage.

Cooke, B., \& Alcadipani, R. 2015. Towards a global history of management education: The case of the Ford Foundation and the São Paulo School of Business Administration. Academy of Management Learning \& Education, 14(4): 482-499.

Cooke, B., \& Mills, A. J. 2008. The right to be human and human rights: Maslow, McCarthyism and the death of humanist theories of management. Management $\mathcal{E}$ Organizational History, 3(1): 27-47.
Cooke, B., Mills, A. J., \& Kelley, E. S. 2005. Situating Maslow in Cold War America: A recontextualization of management theory. Group \& Organization Management, 30(2): 129-152.

Cullen, D. 1997. Maslow, monkeys and motivation theory. Organization, 4(3): 355-373.

Cummings, S., \& Bridgman, T. 2011. The relevant past: Why the history of management should be critical for our future. Academy of Management Learning $\mathcal{F}$ Education, 10(1): 77-93.

Cummings, S., \& Bridgman, T. 2016. The limits and possibilities of history: How a wider, deeper, and more engaged understanding of business history can foster innovative thinking. Academy of Management Learning $\boldsymbol{E}$ Education, 15(2): 250-267.

Cummings, S., Bridgman, T., \& Brown, K. 2016. Unfreezing change as three steps: Rethinking Kurt Lewin's legacy for change management. Human Relations, 69(1): 33-60.

Cummings, S., Bridgman, T., Hassard, J., \& Rowlinson, M. 2017. A new history of management. Cambridge, UK: Cambridge University Press.

Davis, K. 1957. Human relations in business. New York: McGraw-Hill.

Davis, K. 1959. A management teacher by any other name.... Academy of Management Journal, 2(3): 197-199.

De Bruyckere, P., Kirschner, P. A., \& Hulshof, C. D. 2015. Urban myths about learning and education. Saint Louis, MO: Elsevier.

Dye, K., Mills, A. J., \& Weatherbee, T. 2005. Maslow: Man interrupted: Reading management theory in context. Management Decision, 43(10): 1375-1395.

Eaton, S. E. 2013. Maslow's hierarchy of needs - Is Maslow's Pyramid a hoax? Retrieved from https:// drsaraheaton.wordpress.com/2012/08/04/maslowshierarchy-of-needs/

Fineman, S., \& Gabriel, Y. 1994. Paradigms of organizations: An exploration in textbook rhetorics. Organization, 1(2): 375-399.

Galbraith, J. R. 1971. Matrix organizational designs. Business Horizons, 14(1): 29-40.

Genoe McLaren, P., Mills, A. J., \& Weatherbee, T. G. (Eds.). 2015. The Routledge companion to management and organizational history. New York: Routledge.

Gergen, K. J. 1973. Social psychology as history. Journal of Personality and Social Psychology, 26(2): 309-320.

Gordon, R., \& Howell, J. 1959. Higher education for business. New York: Columbia University Press.

Grant, J. D., \& Mills, A. J. 2006. The quiet Americans: Formative context, the Academy of Management 
leadership, and the management textbook, 19361960. Management \& Organizational History, 1(2): 201-224.

Haggbloom, S. J., et al. 2002. The 100 most eminent psychologists of the 20th century. Review of General Psychology, 6(2): 139-152.

Haire, M. 1956. Psychology in management. New York: McGraw-Hill.

Hall, D. T., \& Nougaim, K. E. 1968. An examination of Maslow's need hierarchy in an organizational setting. Organizational Behavior and Human Performance, 3: 12-35.

Hassard, J. 2012. Rethinking the Hawthorne Studies: The Western Electric Research in its social, political and historical context. Human Relations, 65(11): 14311461.

Hitt, M. A., Black, J. S., Porter, L. W., \& Hanson, D. 2007. Management. Frenchs Forest, NSW: Pearson Education Australia.

Hoffman, E. 1988. The right to be human: A biography of Abraham Maslow. Los Angeles, CA: Jeremy P. Tarcher, Inc.

Hoffman, E. 1999. The right to be human: A biography of Abraham Maslow, Rev. ed. New York: McGraw-Hill.

Hoslett, S. D. (Ed.). 1946. Human factors in management. New York: Harper \& Brothers.

Huhn, M. P., \& Dierksmeier, C. 2016. Will the real A. Smith please stand up! Journal of Business Ethics, 136(1): 119-132.

Huizinga, G. 1970. Maslow's need hierarchy in the work situation. Groningen, Netherlands: Wolters-Noordhoff.

Hunger, J. D., \& Wheelen, T. L. 1980. A performance appraisal of undergraduate business education. Human Resource Management, 19(1): 24-31.

Jacques, R. S. 1996. Manufacturing the employee: Management knowledge from the 19th to 21st centuries. London: Sage.

Jacques, R. S. 2006. History, historiography and organization studies: The challenge and the potential. Management \& Organizational History, 1(1): 31-49.

Jacques, R. S., \& Durepos, G. 2015. A history of management histories: Does the story of our past and the way we tell it matter? In P. Genoe McLaren, A. J. Mills, \& T. G. Weatherbee (Eds.), The Routledge companion to management and organizational history: 96-111. New York: New York: Routledge.

Kaplan, S. 2011. Strategy and PowerPoint: An inquiry into the epistemic culture and machinery of strategy making. Organization Science, 22(2): 320-346.

Kenrick, D. T., Griskevicius, V., Neuberg, S. L., \& Schaller, M. 2010. Renovating the pyramid of needs: Contemporary extensions built upon ancient foundations. Perspectives on Psychological Science, 5(3): 292-314.

Klein, D. B. 1942. Psychology's progress and the armchair taboo. Psychological Review, 49(3): 226-234.

Knight, E., Paroutis, S., \& Heracleous, L. 2017. The power of PowerPoint: A visual perspective on meaning making in strategy. Strategic Management Journal, 10.1002/smj.2727.

Knights, D., \& Willmott, H. 1974/75. Humanistic social sciences and the theory of needs. Interpersonal Development, 5: 213-222.

Koltko-Rivera, M. E. 2006. Rediscovering the later version of Maslow's hierarchy of needs: Self-transcendence and opportunities for theory, research, and unification. Review of General Psychology, 10(4): 302-317.

Kremer, W., \& Hammond, C. 2013. Abraham Maslow and the pyramid that beguiled business. Retrieved from http://www.bbc.com/news/magazine-23902918.

Langer, W. C. 1937. Psychology and human living. New York: Appleton-Century-Crofts.

Larson, C. L., Aronoff, J., \& Stearns, J. J. 2007. The shape of threat: Simple geometric forms evoke rapid and sustained capture of attention. Emotion (Washington, D.C.), 7(3): 526-534.

Lawler, E. E., \& Suttle, J. 1972. A casual correlational test of the need hierarchy concept. Organizational Behavior and Human Performance, 7: 265-287.

Lidwell, W., Holdon, K., \& Butler, J. 2003. Universal principles of design. Beverly, Mass: Rockport Publishers.

Lowry, R. J. 1973. A. H. Maslow: An intellectual portrait. Monterey, CA: Brooks/Cole.

Macnab, M. 2008. Decoding design: Understanding and using symbols in visual communication. Cincinnati, $\mathrm{OH}$ : How Books.

Maslow, A. H. 1943. A theory of human motivation. Psychological Review, 50(4): 370-396.

Maslow, A. H. 1954. Motivation and personality. New York: Harper \& Row.

Maslow, A. H. 1957. Letter to McGregor, October 9. Maslow Papers M397, Archives of the Center for the History of Psychology, University of Akron.

Maslow, A. H. 1962. Toward a psychology of being. Princeton: D. Van Nostrand.

Maslow, A. H. 1965. Eupsychian management: A journal. Homewood, IL: Richard D. Irwin Inc. \& The Dorsey Press.

Maslow, A. H. 1970. In W. G. Holtzman \& G. Murphy (Eds.), Motivation and personality (2nd Ed.). New York: Harper \& Row.

Maslow, A. H. 1972. Abraham H. Maslow: A memorial volume. Monterey, CA: Brooks/Cole. 
Maslow, A. H. 1974. Creativity in self-actualizing people. In T. M. Covin (Ed.), Readings in human development: A humanistic approach: 107-117. New York: MSS Information Corp. (Publication of original lecture given in 1958).

Maslow, A. H. 1979a. In R. J. Lowry (Ed.), The journals of A. H. Maslow (Vol. I). Monterey, CA: Brooks/Cole.

Maslow, A. H. 1979b. In R. J. Lowry (Ed.), The journals of A. H. Maslow (Vol. II). Monterey, CA: Brooks/Cole.

Maslow, A. H. 1987. In R. Frager \& J. Fadiman (Eds.), Motivation and personality (3rd ed.). New York: Harper \& Row.

Maslow, A. H. 1998. In D. C. Stephens \& G. Heil (Eds.), Maslow on management. New York: John Wiley \& Sons.

Matteson, M. T. 1974. Some reported thoughts on significant management literature. Academy of Management Journal, 17(2): 386-389.

McGuire, S. 2019. 9 types of infographics and when to use them. Retrieved from https://venngage.com/blog/9types-of-infographic-template/. February 5, 2019.

McDermid, C. D. 1960. How money motivates men. Business Horizons, 3(4): 93-100.

McGregor, D. M. 1946. The conditions of effective leadership. In S. D. Hoslett (Ed.), Human factors in management: 39-51. New York: Harper \& Brothers.

McGregor, D. M. 1956. Letter to Maslow, November 16. Maslow Papers M395, Archives of the History of American Psychology, University of Akron.

McGregor, D. M. 1957. Letter to Maslow, September 26. Maslow Papers M397, Archives of the History of American Psychology, University of Akron.

McGregor, D. M. 1957a. The human side of enterprise. In Adventure in thought and action, Proceedings of the Fifth Anniversary Convocation of the School of Industrial Management, Massachusetts Institute of Technology, Cambridge, MA, April 9.

McGregor, D. M. 1957b. The human side of enterprise. Management Review, 46(11): 22-28.

McGregor, D. M. 1960. The human side of enterprise. New York: McGraw-Hill.

Michel, K. L. 2014. Maslow's hierarchy connected to Blackfoot beliefs. Retrieved from https://lincolnmichel. wordpress.com/2014/04/19/maslows-hierarchyconnected-to-blackfoot-beliefs/

Mills, A. J., Simmons, T., \& Helms Mills, J. C. 2005. Reading organization theory: Critical approaches to the study of behaviour and structure in organizations (3rd ed.). Toronto: Garamond Press.

Mills, A. J., Weatherbee, T. G., \& Durepos, G. 2014. Reassembling Weber to reveal the-past-as-history in Management and Organization Studies. Organization, 21(2): 225-243.

Newman, E. J., Garry, M., Bernstein, D. M., Kantner, J., \& Lindsay, D. S. 2012. Nonprobative photographs (or words) inflate truthiness. Psychonomic Bulletin $\mathcal{E}$ Review, 19: 969-974.

O’Shea, J., \& Madigan, C. 1997. Dangerous company. New York: Random House.

Payne, R. 1970. Factor analysis of a Maslow-type need satisfaction questionnaire. Personnel Psychology, 23: 251-268.

Pellegrin, R. F., \& Coates, C. H. 1957. Executives and supervisors: Contrasting definitions of career success. Administrative Science Quarterly, 1(4): 506-517.

Peterson, C., \& Park, N. 2010. What happened to self-actualization? Commentary on Kenrick et al. (2010). Perspectives on Psychological Science, 5(3): 320-322.

Pierson, F. 1959. The education of American businessmen: A study of university-collegiate programs in business education. New York: McGraw-Hill.

Porter, L. W. 1961. A study of the perceived need satisfactions in bottom and middle management jobs. The Journal of Applied Psychology, 45(1): 1-10.

Porter, L. W., Lawler, E. E., \& Hackman, J. R. 1975. Behavior in organizations. New York: McGraw-Hill.

Prichard, C. 2002. Creative selves? Critically reading 'creativity' in management discourse. Creativity and Innovation Management, 11(4): 265-276.

Prieto, L. C., Phipps, S. T. A., Osiri, J. K., \& LeCounte, J. F. 2017. Creating an interface: Aiding entrepreneurial success via critical pedagogy and insights from African-American management history. Journal of Management History, 23(4): 489-506.

Robbins, S. P. 1979. Organizational behavior: Concepts and controversies (1st ed.). Englewood Cliffs, NJ: Prentice-Hall.

Robbins, S. P. 1984. Management: Concepts and practices. Englewood Cliffs, NJ: Prentice-Hall.

Robbins, S. P., Bergman, P., Stagg, I., \& Coulter, M. 2015. Management (7th ed.). Sydney, NSW: Pearson Australia.

Robbins, S. P., \& Judge, T. A. 2015. Organizational behavior (16th Global ed.). Harlow, UK: Pearson.

Rowan, J. 1998. Maslow amended. Journal of Humanistic Psychology, 38(1): 81-92.

Salancik, G. R., \& Pfeffer, J. 1977. An examination of needsatisfaction models of job attitudes. Administrative Science Quarterly, 22(3): 427-456.

Schaller, M., Neuberg, S. L., Griskevicius, V., \& Kenrick, D. T. 2010. Pyramid power: A reply to commentaries. 
Perspectives on Psychological Science, 5(3): 335337.

Schein, E. 2015. Organizational psychology then and now: Some observations. Annual Review of Organizational Psychology and Organizational Behavior, 2: $1-19$.

Schermerhorn, J. R., Davidson, P., Poole, D., Woods, P., Simon, A., \& McBarron, E. 2014. Management: Foundations and applications (2nd Asia-Pacific ed.). Milton, Queensland: John Wiley \& Sons Australia.

Stephens, D. C. 2000. Introduction. In D. C. Stephens (Ed.), The Maslow business reader: 1-2. New York: John Wiley \& Sons.

Stephens, D. C., \& Heil, G. 1998. Introduction. In D. C. Stephens \& G. Heil (Eds.), Maslow on management: $\boldsymbol{x} \boldsymbol{V}$-xx. New York: John Wiley \& Sons.

Strauss, G., \& Sayles, L. R. 1960. Personnel: The human problems of management. Englewood Cliffs, NJ: Prentice-Hall.

Talking About Organizations 2015. Episode 3. What people want - Maslow's theory of human motivation. Retrieved from https://www.talkingaboutorganizations. $\mathrm{com} / \# /$ maslow/

Vroom, V. 1967. Maslow at play: A review of Eupsychian Management: A Journal by Abraham H. Maslow. Contemporary Psychology: A Journal of Reviews, 12(2): 97-98.

Wahba, M. A., \& Bridwell, L. G. 1976. Maslow reconsidered: A review of research on the need hierarchy theory. Organizational Behavior and Human Performance, 15: 212-240.

Wang, C. 2015. The psychological meanings behind familiar shapes (and how to use them). Retrieved from http://www.shutterstock.com/blog/psychologicalmeaning-shapes-use.

Waterman, R. H., Peters, T. J., \& Phillips, R. B. 1980. Structure is not organization. Business Horizons, 23(3): 14-26.

Watson, T. J. 1996. Motivation: That's Maslow, isn't it? Management Learning, 27(4): 447-464.
Wheelen, T. L., \& Hunger, J. D. 1983. Strategic management and business policy. Reading, MA: Addison-Wesley.

Wilber, K. 2000. Integral psychology. Boston, MA: Shambhala.

Wininger, S. R., \& Norman, A. D. 2010. Assessing coverage of Maslow's theory in educational psychology textbooks: A content analysis. Teaching Educational Psychology, 6(1): 33-48.

Wren, D. A. 1972. The evolution of management thought. New York: Ronald Press.

Wren, D. A. 2002. History is chapter 2: Are we teaching fallacies? Paper presented at the Southwest Academy of Management Annual Meeting, St. Louis, Missouri.

Wren, D. A., \& Bedeian, A. G. 2009. The evolution of management thought (6th ed.). New York: Wiley.

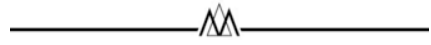

Todd Bridgman ( $\mathrm{PhD}$, University of Cambridge, todd. bridgman@vuw.ac.nz) is an associate professor of management at Victoria University of Wellington, New Zealand. His research interests lie at the intersection of management history, management education, and critical management studies.

Stephen Cummings ( $\mathrm{PhD}$, University of Warwick, stephen. cummings@vuw.ac.nz) is professor of strategy at Victoria University of Wellington, New Zealand. His current research interests include the history of the formation of management and of business schools, and alternative approaches to strategy formulation and communication.

John Ballard ( $\mathrm{PhD}$, Purdue University, social/personality psychology, john.ballard@msj.edu) is emeritus professor of management at Mount St. Joseph University, Cincinnati, Ohio. He has over 25 years of consulting and managerial experience and is author of Decoding the Workplace. His research, blogging (www.johnballardphd.com), and tweeting (@JohnBallardPhD) focus on bridging the gap between management scholars and practitioners. 